\title{
Bierce, Bioy Casares, and Borges: The Mirrors and Labyrinths of Intertextuality
}

\author{
William Deaver ${ }^{1}$
}

This article analyzes the intersection of works by Ambrose Bierce, Adolfo Bioy Casares, and Jorge Luis Borges as mirror images of themes and descriptions in describing a miraculous occurrence, albeit only in the labyrinthine mind of the protagonist, often categorized within the genre of the fantastic. The article's intertextual approach focuses on sensorial perceptions that only grant validity to an internal reality (what the mind interprets) rather than to an external reality (what the eyes see). All three works in this study are concerned with a criminal condemned to death who seeks to prolong his life. The protagonists have similar responses, although their motivations are different. [Article copies available for a fee from The Transformative Studies Institute. E-mail address: journal@transformativestudies.org Website: http://www.transformativestudies.org (C2020 by The Transformative Studies Institute. All rights reserved.]

KEYWORDS: Bierce, Bioy Casares, Borges, Mirrors, Labyrinths.

Amb rose Bierce's "An Occurrence at Owl Creek Bridge" (1890) and Adolfo Bioy Casares's La invención de Morel (1940) prefigure Jorge Luis Borges's "El milagro secreto" (1944). In all three works, the narrator's imminent death disrupts time and reality affecting the protagonists' sense of perception. Essentially, this intertextuality reenvisions the earlier works, reflecting a likeness that differs from the original yet is similar, albeit distorted. As Zheyla Henriksen notes, "El modo como funcionan los cuentos de Borges está más allá no sólo dentro de otro símbolo escondido en el mismo relato, sino en otros relatos..."

\footnotetext{
${ }^{1}$ William O. Deaver, Jr., Ph.D., was a professor of Spanish at Georgia Southern University in Savannah, Georgia. He held a B.A. in English from the University of Virginia, an M.A. in Spanish from the University of Virginia, and a Ph.D. in Spanish from Florida State University. His publications include articles on Spanish and Spanish American film and literature as well as Hispanic literature of the United States. His main area of focus had been the Caribbean; specifically, Gabriel García Márquez, Tomás Gutiérrez Alea, Roberto G. Fernández, Virgil Suárez, Elías Miguel Muñoz, and Miguel Piñero. He passed away suddenly and unexpectedly on April $28^{\text {th }}, 2019$.
} 